\title{
$275 \mathrm{kV} 2$ 回線送電線の五相地絡事故
}

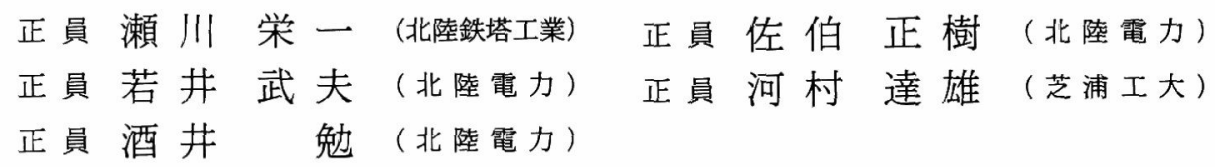

Five Line-to-Ground Fault in $275 \mathrm{kV}$ Double-Circuit Transmission Line Eiichi Segawa, Member, Takeo Wakai, Member, Tsutomu Sakai, Member, Masaki Saiki, Member (Hokuriku Electric Power Co.), Tatsuo Kawamura, Member, (Sibaura Institute of Technology)

キーワード：雷電流，冬季雷，送電線

1.はじめに

日本海沿岸地区の $275 \mathrm{kV}$ 以上の超高圧送電線（標 高 $300 \mathrm{~m}$ を超え, 更に日本海からの冬季季節風が吹 き抜ける地域を通過）では，冬期にのみ超高圧送電線 の 2 回線事故が発生している(1)。このような超高压送 電線での 2 回線事故の原因は十分解明されていな い(2)(3)。著者らは平成 2 年 11 月から，敦賀および武 生地区において大地放電, 鉄塔落雷, 雲間放電の様相 を静止写真により観測し, 送電線への雷撃実態の把握 を試みてきた。当地区では送電線が輻輳しているが, これらのうち $275 \mathrm{kV} A$ 線と $154 \mathrm{kV} \mathrm{B}$ 線を主な観測 対象としている。

本レターでは, 超高圧送電線の架空地線への雷撃に より，鉄塔で逆フラッシオーバが発生し，五相地絡に 至っている静止写真が撮影できたことについて報告す る。

2. 観 測 体 制

測定項目は，鉄塔雷撃電流測定とカメラによる雷放 電路撮影であり，いずれも無人で観測している。雷撃 電流は，磁鋼片（194 基，776 個），回転型磁鈵片（5 基, 20 台), 雷サージカウン夕（6基，24台), 雷サ ージメモリー (3 基, 3 台 $)^{(4)}$ を鉄塔塔脚に設置して測 定している。雷放電路の撮影は，長波尾雷力メラ 11 台, 多重雷力メラ 2 台を配電柱および鉄塔に設置し て，雷撃時の光を検知することにより撮影できるよう にしている。また， $275 \mathrm{kV} A$ 線の架空地線に変流器 が設置されておりこれらにより雷撃時の電流波形

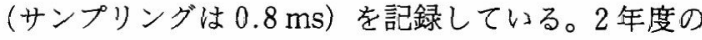

観測において，図 1 に示すような雷撃による特異な鉄 塔逆フラッシオーバ現象をカメラ撮影することに成功 した。すなわち，平成 2 年 12 月 16 日 14 時 44 分 4 秒 に275 kVA線で2 回線トリップ（五相地絡事故 相: $1 L: R \cdot S$ (上・中] $2 L: T \cdot S \cdot R$ (上・中・下)) が発生している。一方, 雷カメラによる困 1 は 16 $14 ： 43$ と 16 日 14 時 43 分と時刻表示しているので, このトリップの瞬間をとらえていると推定する。雷撃 地点は 16 号鉄塔から 17 号鉄塔へ向けて約 $40 \mathrm{~m}$ 進ん だ架空地線である。これと同時に 16 号鉄塔における 逆フラッシオーバ現象が記録されている。

昼に撮影した写真より, 三次元グラフィックス処理

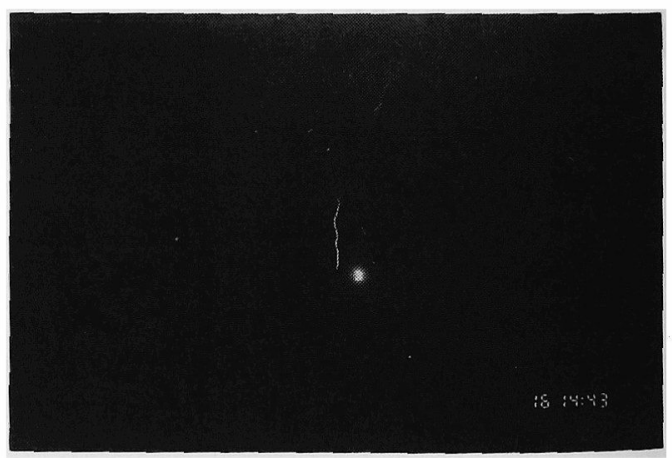

図 11990 年 12 月 16 日 14 時 44 分 4 秒, $275 \mathrm{kV} \mathrm{A}$ 線 No. 16 鉄塔で発生した 五相地絡事故の静止写真

Fig. 1. Five line-to-ground fault at No. 16 tower of $275 \mathrm{kV}$ transmission line (14: 44 JST on Dec. 16, 1990).

T. IEE Japan, Vol. 113-B, No. 11, '93 


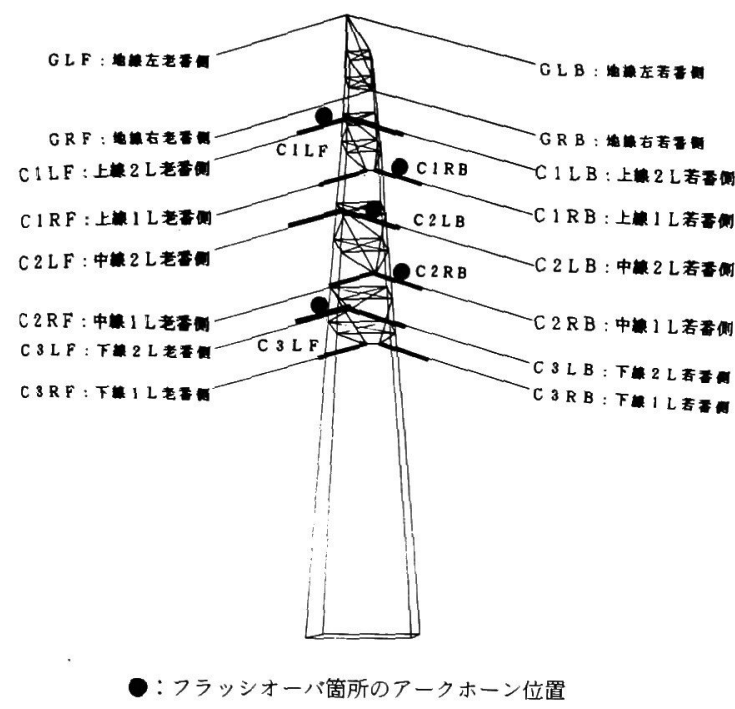

図 $2275 \mathrm{kV} A$ 線鉄塔逆フラッシオーバ時

のグラフィック表示

Fig. 2. Graphics of back-flashover at iron steal of $275 \mathrm{kV}$ transmission line.

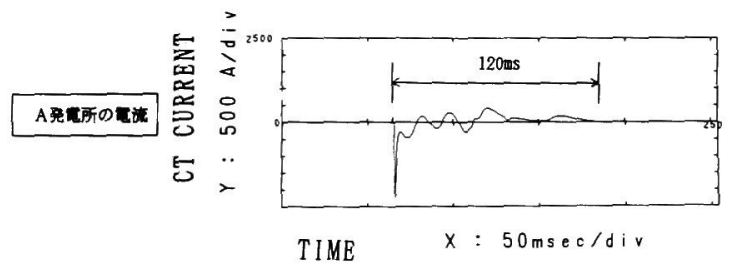

図 $3275 \mathrm{kV} A$ 線の架空地線に流れた電流波形

Fig. 3. Waveforms of current flowed through ground-wire of $275 \mathrm{kV}$ transmission line.

から鉄塔周辺を再現したものを図 2 に示す。図 1 を拡 大して重ね合わせた結果，図 2 の印の部分がフラッ シオーバした部分であると推定される。更に・印の相 は事故相と一致する。

このとき雷撃電流は 16 号鉄塔の磁鋼片では, 負極 性 $25 \mathrm{kA}$ の電流（4 脚の合計）が記録された。A発 電所の架空地線に流れた電流の継続時間は, 図 3 に見 られるように約 $120 \mathrm{~ms}$ であった（ $A$ 発電所から 16 号鉄塔までの距離は $5,944 \mathrm{~m})$ 。このことは, リレー が高速再閉路に失敗（66 ms 以上継続した場合）して おり,その後, 中速再閉路に成功 (20秒後)してい ることからも裏づけられる。

最後に, 本研究に協力していただいた北陸電力(株) 福井支店技術担当, 同武生電力所の方々, および研究 に対して御教示をいただいた電力中央研究所の方々に 謝意を表します。

(平成 5 年 4 月 26 日受付)

\section{文献}

（1）耐雷技術委員会送電線分科会: 送電線雷事故統計（昭和 $55 \sim 59$ 年度 5 箅年統計), T 86803

（2）井上·三谷・多田・藤波・三宅・稲場・小林・田村：「154 kV 敦賀線における冬季雷観測結果 (昭和 58 年度) 」, 電気学会放 電・高電圧合同研資, HV 84-33 (昭 59)

（3）井上・本山・三木・清水：「154 kV 敦賀線における冬季雷観 測結果昭 63 年度一逆フラッシオーバ時のがいし間電圧一」, 同上, HV 90-33 (平 2)

(4) 雷撃特性調查專門委員会「最近に扔ける雷研究の動向と問題 点」, 電気学会技報 (II部), No.278 (昭 63)

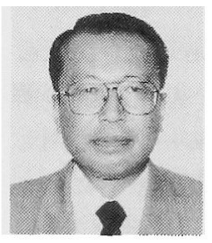

同社常任顧問。
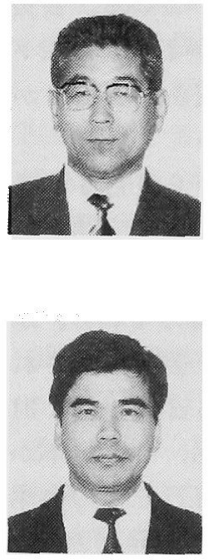

\section{酒 井勉 (正員)}

昭和 17 年 4 月 14 日生。36 年 3 月富 山工業高等学校電気科卒業。同年北陸電 力(株) 入社, 平成 3 年同社技術研究所勤 務。現在, 同所副課長。

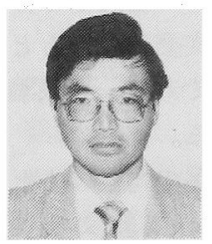

佐 伯 正 樹（正員）

昭和 29 年 7 月 5 日生。 54 年 3 月金沢 大学大学院工学研究科電気工学専攻修士 課程修了。同年北陸電力 (株) 入社, 現在 に至る。

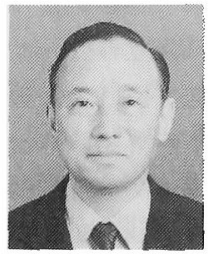

河 村 達 雄 (正員)

昭和 5 年 8 月 16 日生。 34 年 3 月東京 大学大学院数物系統博士課程修了。同年 4 月同大学生産技術研究所勤務。平成 3 年 4 月芝浦工業大学教授, 現在に至る。 工学博士。 